唾液腺ホルモンの Subunit に関する生理化学的研究(その2)

大阪大学薬学部

青沼 繁, 小浜 靖弘, 中陳 静男, 屋敷 伸治

江川宏, 和田 昌師, 小宮山 豊

\title{
The Study of Physiological Chemistry on a Subunit of Salivary Gland Hormone (2)
}

\author{
Shigeru AONUMA, Yasuhiro KOHAMA, Shizuo NAKAJIN, Shinji YASHIKI, \\ Hiroshi EGAWA, Masanori WADA and Yutaka KOMIYAMA \\ Faculty of Pharmaceutical Sciences, Osaka University
}

It had been reported by authors that salivary gland hormone, parotin, was composed with subunit (parotin-subunit) which showed molecular weight of 45,000, and that parotin-subunit had rabbit serum calcium decreasing activity and the cross reactivity with rabbit anti parotin serum. In the present report, in order to study physiological chemistry of parotin-subunit, the influence of parotin-subunit on serum $\mathrm{Ca}$ and ${ }^{45} \mathrm{Ca}$ levels relating to calcium metabolism, the distribution of ${ }^{131} \mathrm{I}$-parotin-subunit, the effect of parotin-subunit on adenyl cyclase-cyclicAMP system, the anabolic action, C-terminal amino acid sequence and sugar component of parotin-subunit were investigated. The results are summarized as follows:

1) The decrease of rabbit serum $\mathrm{Ca}$ after injection of parotin-subunit was related to change of $\mathrm{Ca}$ in stable bone, but not to inhibition of bone resorption.

2) A high concentrated localization of radioactivity of ${ }^{131} I$-parotin-subunit was found in liver, kidney and spleen, and as much as $60 \%$ of administrated radioactivity was localized in liver at $5 \mathrm{~min}$ after the injection. The retention of radioactivity was found in testis, seminal vesicle, prostate, parotid gland and submaxillary gland.

3) Cyclic AMP level increased significantly in metaphysial bone, submaxillary gland and plasma after administration of parotin-subunit but in other organs with localized much radioactivities, the level did not changed. Parotin-subunit activated adenyl cyclase of particular fraction of metaphysial bone.

4) The C-terminal amino acid of parotin-subunit was Leu, and its C-terminal amino acid sequence was -Val-Ser-Ala-Thr- Leu-OH by digestion of carboxypeptidase A.

5) Parotin-subunit included $3.3 \%$ of sugar which consisted of amino sugar and uronic acid. 
緒 言

牛耳下腺より抽出精製した荰液腺ホルモン活性分画であるいわゆる MP-Parotin から, 著者らは分子量 45, 000の Parotin-Subunit の精彆, 単離に成功しすでに報告した ${ }^{11}$. この Parotin-Subunit は原料として 用いた MP-Parotin 同様家鬼血清 Ca 低下作用を有し, 免度化学的にもParotin と交叉するととから"1, 本報では Parotin-Subunit が喠液腺ホルモン作用本態ではないかと考え，その生理化学的性質について種 々検討を加えた.すなわち作用機作解明の一端として Ca 代謝調節に対する影響および ${ }^{131}$ I-Parotin-Subunit の生体内分布を調べるともに，多くのホルモンにみられるように Adenyl cyclase-Cyclic AMP 系を介 してのホルモン作用発現の可能性を考え, Adenyl cyclase-Cyclic AMP 系に対してどのような影響を与え るか検討を加えた。ささらに Parotin Subunit の anabolic 作用並びにC末端アミノ酸配列, 構成糖成分な どの化学的諸性質についても知見を得たので報告する.

\section{実 験 方 法}

\section{MP-Parotin および Subunit の調製}

既報”に従い分離精製した。

家鬼血清 $\mathbf{C a}$ および ${ }^{45} \mathbf{C a}$ レベルの測定

既報1) 亿従って行なった。

${ }^{131}$ I-Parotin-Subunit のラット生体内分布の測定

i) Parotin-Subunit のヨウ素化

クロラミン T 法 ${ }^{10 !}$ により Parotin-Subunit をヨウ素化した。 すなわち $\mathrm{Na}^{131} \mathrm{I}(11 \mathrm{mCi} / \mathrm{ml}) 1 \mathrm{mCi}$ を 用いバイアル中で Parotin-Subunit $3 \mathrm{mg}$ をヨウ素化し Sephadex G-25 のカラムを用い ${ }^{131} \mathrm{I}$-ParotinSubunit を反応混合液から分離精製した。な敃得られた ${ }^{131}$ I-Parotin-Subnit の比放射能は $9.7 \times 10^{7} \mathrm{cpm} /$ mg protein であった.

ii）生体内分布の測定

正常雄性ウイスター系ラット（体重90１00 g)を 1 群 4 匹とし， ${ }^{131}$ I-Parotin-Subunit をペントバルビタ 一ル麻酔下に股間静脈より $100 \mu \mathrm{g} / 100 \mathrm{~g}\left(9.7 \times 10^{6} \mathrm{cpm} / 100 \mathrm{~g}\right)$ の投与量で注射した. 所定時間後に撲殺潟 血させた後, 下垂体, 耳下腺, 顎下腺, 甲状腺, 心臓, 胸腺, 肝臓, 脾臓, 副腎, 腎臓, 睪丸, 副性器（精 のう腺および前立腺）および血液を採取し, 各臟器を秤量後, 肝臓, 腎臓, 睪丸はその一部を, 他の臟器は 全量を $10 \mathrm{~N}-\mathrm{NaOH}$ に溶解し, ウエルタイプシンチレーションカウンターにてその放射能の測定を行なっ た.

Cyclic AMP の測定

Cyclic AMP の測定は competitive protein binding assay に基づく Cyclic AMP assay kit (The Radiochemical Centre Amersham 製) を用いて行なった。

i) 各臓器中の Cyclic AMP の測定

正常雄性ウィスター系ラット（体重 90 ～100 g ) 1 群 4 匹とし，ペントバルビタール麻酔下に股間静脈 より Parotin-Subunit を $100 \mu \mathrm{g} / 100 \mathrm{~g}$ の投与量で注射し, 生理食塩水のみを投与した正常群と投与後 5 , 20，180分の群を測定した．所定時間後に撲殺潟血させた後すげやく各臓器を採取し，ドライアイスにより 急速江凍結し酵素活性を止めた臟器（湿重量 $250 \sim 500 \mathrm{mg}$, それ以下の藏器は全量）を冷 $6 \% \mathrm{TCA} 2 \mathrm{ml}$ 中 でホモジナイズし, ホモジネートを $4,000 \mathrm{rpm}$ で20分遠心分離し, 上清を 2 倍量のエーテルを用い 6 回抽 出操作を行ない TCA を除去した後, 残存するエーテルを $60^{\circ} \mathrm{C}$ で蒸発除去しその一部を測定試料とした.

ii）血中 Cyclic AMP の定量

撲殺湼血させた血液を $0.5 \mathrm{M}$ EDTA（血液に対して $1 \%$ ) を含む冷試駼管に採取し，酵素活性を止め遠心 分離後血奬を得，その $50 \mu 1$ を測定試料とした. 


\section{Adenyl cyclase 活性の測定}

賦活化された Adenyl cyclase により ATP から転換される Cyclic AMP 量を Cyclic AMP assay kit を用い competitve protein binding assay により測定した.

\section{i) Adenyl cyclase 活性分画の調製}

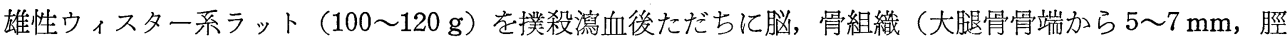
腓骨骨端から 5〜 $7 \mathrm{~mm}$ の関節腔を含む組織，以下骨端部骨と略す）を取り出し，氷冷下 8 倍量の $50 \mathrm{mM}$ Tris-HCl buffer (pH 7.4) を用いホモジナイズし, グラスウールにて沪過後沪液を $2,200 \times \mathrm{g} に 4^{\circ} \mathrm{C}$, 10分間遠心分離を行なった. ${ }^{9 / 17}$ 沈澱を再び 8 倍量の上記の Tris buffer にてホモジナイズし, 同標な操作 を 2 回行なった後 2〜4 $\mathrm{ml}$ の Tris buffer に懸濁したあのを酵素液とし，ただちに活性測定に用いた。な お酵素液の蛋白量は酵素液の一部を Lowry 法 ${ }^{16)}$ により測定し Bovine serum albumin (BSA) 換算量と した.

\section{ii）酵素活性の測定}

$3.2 \mathrm{mM}$ ATP, $10 \mathrm{mM} \mathrm{MgCl}_{2}, 10 \mathrm{mM}$ Theophylline, $0.02 \% \mathrm{BSA}, 50 \mathrm{mM}$ Tris-HCl buffer (pH 7.4) 加成る incubation medium $400 \mu \mathrm{l}$ に水冷下酵素液 $50 \mu \mathrm{l}(300 \sim 500 \mu \mathrm{g}$ 蛋白量)を加え, 更に ParotinSubunit, MP-Parotin 6 100 $\mu \mathrm{g} / \mathrm{ml}$ (終濃度) の溶液 $50 \mu 1$ を加え， $37^{\circ} \mathrm{C}, 15$ 分間振とうしながら incubation を行なった. incubation 終了後沸とう水溶中で 3 分間惹沸し反応を停止させた後 $3,000 \mathrm{rpm}, 10$ 分間遠心分離後上清中の ATP から転換されたCyclic AMP 量を測定した. なお対照として酵素液のみを 加えたものと, Adenyl cyclase 賦活剂として $10 \mathrm{mM} \mathrm{NaF}$ (終濃度) ${ }^{9)}$ を添加したものを同様に incubation し活性測定を行なった.

\section{マウス肛門挙筋法による Parotin-Subunit の Anabolic 作用の検定}

正常雄性 DD 系マウス（体重 20～30 g）を去勢し, Hershberg, Shipley \& Meyer 法19) に準じ 7 日後 検体を毎日 7 日間皮下投与を行なった。検体は Parotin-Subunit および MP-Parotin を生理食塩水に溶

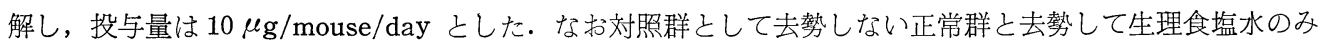
を投与した去勢群を用いた．検体最終投与後 24 時間目に肛門挙筋を摘出しその重量を測定した.

\section{$\mathbf{C}$ 末端アミノ酸配列の同定}

既報2)に從いカルボキシペプチダーゼ $\mathrm{A}$ 法により行なった.すなわち，カルボキシペプチダーゼ $\mathrm{A}$ （シグ マ製) を氷冷下 $1 \% \mathrm{Na}_{2} \mathrm{CO}_{3}$ 溶液および $0.1 \mathrm{~N} \mathrm{NaOH}$ 溶液で溶解後ただちに $0.1 \mathrm{~N} \mathrm{HCl}$ 調製したものを酵素液とし, 検体 $30 \mathrm{mg}$ (約 $0.7 \mu \mathrm{mole}$ ) を $4 \mathrm{ml}$ の再蒸留水に溶解し $0.1 \mathrm{~N} \mathrm{NaOH}$ 溶液 で $\mathrm{pH} 8.2$ に調製後 mole 比で基質の $1 / 50$ 量の酵素液を加え $25^{\circ} \mathrm{C}$ 反応させた. 反応開始後 1 時間, 3 時間および 6 時間後に $1 / 3$ 量の反応液を分取し，10\% TCA を等量加え反応停止後遠心分離した上清をア ミノ酸自動分析計を用い経時的に遊離してくるアミノ酸を定量した.

糖質成分の定性亡定量反応 ${ }^{23)}$

糖質に共通な呈色反応としてアンスロン一硫酸反応およびフェノール硫酸反応，アルドヘキソースの呈色 反応としてクロモトロープ酸-硫酸反応，ケトースの呈色反応としてカルバゾール硫酸反応，ペントースの 呈色反応としてオルシン-塩化鉄-塩酸法, ウロン酸の呈色反応としてカルバゾール硫酸反応㧤よびオルシン第二鉄塩-塩酸反応, アミノ糖の呈色反応として $4 \mathrm{~N}-\mathrm{HCl}$ によ $100^{\circ} \mathrm{C} ， 6$ 時間加水分解した試料について Blix 変法を用いた. またシアル酸の呈色反応としてレゾルシン試薬による定量法を用いた。

\section{沈降平衡法による分子量の測定}

Parotin-Subunit の分子量について既にディスク電気泳動法および沈降, 拡散定数を用いた方法による結果 を報告しているが11，今回さらに沈降平衡法により測定を行なった. すなわち日立 202 型分析用起遠心機を

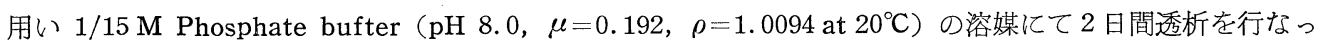
た Parotin-Subunit の $1 \%$ 濃度の試料を用い Archbald 法 ${ }^{11)}$ により測定した. 回転数は 6,500 rpm を用

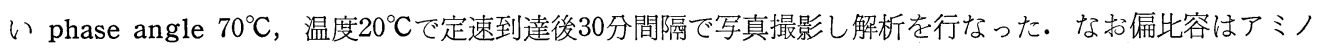


酸分析値より算出し 0.72 であった。

\section{実 験 結 果}

MP-Parotin および Parotin-Subunit の血清 Ca および ${ }^{45} \mathbf{C a}$ に及ぼす影響

Parotin-Subunit が家鬼血清 $\mathrm{Ca}$ 低下作用を有しているとと” から, 家鬼をとり上げ血清 $\mathrm{Ca}$ 量の変動が 骨の不安定分画の Ca および安定分画の Ca のいずれに関与するのかを MP-Parotin および ParotinSubunit を用い検討を加えた. すなわち Johnston らの方法 ${ }^{151}$ に準じ， 5 時間前に ${ }^{45} \mathrm{Ca}$ を投与し骨の不安 定分画をラベルした家鬼と 2 週間前に ${ }^{45} \mathrm{Ca}$ を投与して骨の安定分画をラベルした家鬼においてまず $\mathrm{MP}-$ Parotin 投与後 5 時間目に血清総 $\mathrm{Ca}$ と ${ }^{45} \mathrm{Ca}$ 量の変動を調べた. その結果 Table 1 に示す如く骨の不安

Table 1. Effect of MP-Parotin on Serum Calcium and ${ }^{45} \mathrm{Ca}$ Levels of Rabbit Administrated with ${ }^{45} \mathrm{Ca} 5$ Hours or 2 Weeks Prior

\begin{tabular}{c|l|c|c}
\hline \multicolumn{2}{c|}{ Group } & $\begin{array}{c}\text { Serum Ca } \\
(\mathrm{mg} / \mathrm{dl})\end{array}$ & $\begin{array}{c}\text { Serum }{ }^{45} \mathrm{Ca}^{\mathrm{a})} \\
(\text { change\%) }\end{array}$ \\
\hline \multirow{2}{*}{5 Hours } & $\begin{array}{l}12.64 \pm 0.12 \\
11.58 \pm 0.16^{* *}\end{array}$ & $\begin{array}{c}31.2 \pm 5.2 \\
32.6 \pm 5.4\end{array}$ \\
\hline \multirow{2}{*}{ W Weeks } & MP-Parotin & $12.76 \pm 0.04$ & $95.8 \pm 1.5$ \\
& Control & $11.64 \pm 0.08^{* *}$ & $142.5 \pm 17.4^{*}$ \\
\hline
\end{tabular}

a) value of $5 \mathrm{hr}$ after MP-Parotin injection $(2 \mathrm{mg} / \mathrm{kg}$ )

b) expressed as the change percentage of radioactivity at $0 \mathrm{hr}$ to $5 \mathrm{hr}$

* $\mathrm{p}<0.05, * * \mathrm{p}<0.01$ significant difference from control

定分画をラベルした家兔においては血清総 $\mathrm{Ca}$ 量には有意な変動を認めたが ${ }^{45} \mathrm{Ca}$ 量にはなんら変化は認め られなかった，それに対して骨の安定分画をラベルした家鬼において血清総 Ca 量が有意な変動を示すとと を認めるとともに ${ }^{45} \mathrm{Ca}$ の有意な増加を認めた. MP-Parotin により骨安定分画の Ca の変動が認められた ので，次に骨安定分画への ${ }^{45} \mathrm{Ca}$ が取り込まれるまでの時間について検討を加えた結果，既報 ${ }^{11}$ の Fig. 7 に示すように 3 日目以降から血清 ${ }^{45} \mathrm{Ca}$ レベルが平衡に達することから， ${ }^{45} \mathrm{Ca}$ 投与後 3 日目以降の家鬼を用 い, Parotin-Subunit および MP-Parotin について同様に検討を加えた. その結果 Table 2 に示すよう

Table 2. Effect of MP-Parotin and Parotin-Subunit on Serum Calcium and ${ }^{45} \mathrm{Ca}$ Levels of Rabbit Administrated with ${ }^{45} \mathrm{Ca} 3$ Days Prior

\begin{tabular}{c|l|c|c|c}
\hline \multirow{2}{*}{ Exp. } & Group & Dose & $\begin{array}{c}\text { Serum Ca } \\
(\mathrm{mg} / \mathrm{dl})\end{array}$ & $\begin{array}{r}\text { Serum }{ }^{45} \mathrm{Ca}^{\mathrm{a})} \\
(\text { change } \%)^{\mathrm{b})}\end{array}$ \\
\hline \multirow{2}{*}{ Exp. 1 } & Control & 0 & $12.74 \pm 0.12$ & $95.8 \pm 1.5$ \\
& MP-Parotin & $2 \mathrm{mg} / \mathrm{kg}$ & $11.40 \pm 0.13^{* *}$ & $121.5 \pm 9.2$ \\
\cline { 2 - 4 } Exp. 2 & Control & 0 & $12.89 \pm 0.20$ & $96.8 \pm 1.4$ \\
& Parotin-Subunit & $20 \mu \mathrm{g} / \mathrm{kg}$ & $11.48 \pm 0.25^{* *}$ & $122.6 \pm 9.6$ \\
\hline
\end{tabular}

a) value of $5 \mathrm{hr}$ after sample injection

b) expressed as the persentage of radioactivity at $0 \mathrm{hr}$ to $5 \mathrm{hr}$

** $\mathrm{p}<0.01$ significant difference from control 
にParotin-Subunit $20 \mu \mathrm{g} / \mathrm{kg}$ の投与量で投与した場合 MP-Parotin と同様血清総 Ca 量の有意な減少 と ${ }^{45} \mathrm{Ca}$ の増加を認めた. 以上のことから MP-Parotin および Parotin-Subunit の有する血清 $\mathrm{Ca}$ 量の低 下作用は骨安定分画の Ca の移動に関与することを認めた.

${ }^{131}$ I-Parotin-Subunit のラット生体内分布

Parotin-Subunit の生体内分布を調べる目的で ${ }^{131}$ I-Parotin-Subunit を用いラットにおいてその分布さ

Table 3. Distribution of Radioactivity into Various Tissues of Rat

Administrated with ${ }^{131} \mathrm{I}$-Parotin-Subunit (1)

\begin{tabular}{|c|c|c|c|c|c|}
\hline \multirow{2}{*}{ Tissues } & \multicolumn{5}{|c|}{ Time after injection ${ }^{\text {a) }}(\mathrm{min})$} \\
\hline & 5 & 20 & 60 & 180 & \\
\hline Blood & $427.9 \pm 18.2^{\mathrm{b})}$ & $176.0 \pm 31.9$ & $171.7 \pm$ & $108.7 \pm$ & 6.5 \\
\hline Hypophysis & $180.9 \pm 17.1$ & $183.7 \pm 14.1$ & $129.0 \pm$ & $125.7 \pm$ & 4.6 \\
\hline Parotid gland & $25.4 \pm 1.2$ & $26.7 \pm 6.5$ & $52.4 \pm$ & $47.5 \pm$ & 0.7 \\
\hline Submaxillary gland & $35.0 \pm 1.9$ & $40.9 \pm 7.2$ & $60.7 \pm 5.5$ & $40.4 \pm$ & 2.2 \\
\hline Thyroid & $131.6 \pm 22.2$ & $645.4 \pm 182.6$ & $3859.3 \pm 1686.0$ & $25010.8 \pm$ & 7.8 \\
\hline Heart & $48.7 \pm 4.6$ & $43.6 \pm 8.2$ & $46.5 \pm 3.4$ & $32.7 \pm$ & 1.8 \\
\hline Thymus & $15.4 \pm 0.6$ & $26.5 \pm 4.1$ & $40.7 \pm$ & $34.7 \pm$ & 3.4 \\
\hline Liver & $1571.7 \pm 173.6$ & $1323.9 \pm 119.6$ & $232.3 \pm 3.2$ & $41.5 \pm$ & 7.7 \\
\hline Spleen & $548.5 \pm 73.2$ & $538.9 \pm 3.7$ & $179.2 \pm 13.6$ & $68.4 \pm$ & 6.8 \\
\hline Kidney & $576.3 \pm 27.2$ & $618.4 \pm 39.0$ & $244.7 \pm 11.7$ & $132.2 \pm$ & 4.7 \\
\hline Adrenal & $120.3 \pm 7.1$ & $133.8 \pm 4.6$ & $66.4 \pm 6.4$ & $42.4 \pm$ & 1.0 \\
\hline Testis & $9.7 \pm 0.4$ & $17.8 \pm 2.6$ & $44.4 \pm$ & $48.2 \pm$ & 0.7 \\
\hline $\begin{array}{l}\text { Seminal vesicle } \\
\text { Prostate }\end{array}$ & $23.1 \pm 2.6$ & $37.6 \pm 4.1$ & $58.4 \pm$ & 51. $9 \pm$ & \\
\hline
\end{tabular}

a) Rat was injected intravenously with $100 \mu \mathrm{g}$ of ${ }^{131} \mathrm{I}$-Parotin-Subunit $\left(9.7 \times 10^{6} \mathrm{cpm}\right) / 100 \mathrm{~g}$ rat. b) $\mathrm{cpm} / \mathrm{mg}$ wet tissue (mean \pm S.E.)

Table 4. Distribution of Radioactivity into Various Tissues of Rat Administrated with ${ }^{181}$ I-Parotin-Subunit (2)

\begin{tabular}{|c|c|c|c|c|c|c|c|c|}
\hline \multirow{2}{*}{ Tissues } & \multicolumn{8}{|c|}{ Time after injection a) $(\min )$} \\
\hline & & 5 & & 20 & & 60 & & 80 \\
\hline Hypophysis & 0.0070 & $\pm 0.0005^{\mathrm{b})}$ & 0.0059 & \pm 0.0003 & 0.0049 & \pm 0.0003 & $0.0039 \pm$ & \pm 0.0001 \\
\hline Parotid gland & 0.062 & \pm 0.006 & 0.071 & \pm 0.021 & 0.136 & \pm 0.010 & $0.142 \pm$ & \pm 0.005 \\
\hline Submaxillary gland & 0.081 & \pm 0.007 & 0.075 & \pm 0.009 & 0.105 & \pm 0.014 & 0.082 & \pm 0.003 \\
\hline Thyroid & 0.013 & \pm 0.017 & 0.053 & \pm 0.014 & 0.357 & \pm 0.149 & 2.10 & \pm 0.213 \\
\hline Heart & 0.202 & \pm 0.028 & 0.160 & \pm 0.016 & 0.172 & \pm 0.029 & 0.113 & \pm 0.003 \\
\hline Thymus & 0.037 & \pm 0.004 & 0.063 & \pm 0.017 & 0.105 & \pm 0.018 & 0.081 & \pm 0.013 \\
\hline Liver & 57.65 & \pm 4.90 & 54.53 & \pm 5.87 & 10.09 & \pm 0.56 & 5.94 & \pm 0.47 \\
\hline Spleen & 1.53 & \pm 0.09 & 1.53 & \pm 0.12 & 0.54 & \pm 0.03 & 0.21 & \pm 0.02 \\
\hline Kidney & 6.56 & \pm 0.46 & 6.09 & \pm 0.44 & 2.44 & \pm 0.08 & 1.40 & \pm 0.05 \\
\hline Adrenal & 0.037 & \pm 0.004 & 0.062 & \pm 0.017 & 0.105 & \pm 0.018 & 0.081 & \pm 0.013 \\
\hline Testis & 0.121 & \pm 0.005 & 0.192 & \pm 0.035 & 0.493 & \pm 0.033 & $0.541 \pm$ & \pm 0.031 \\
\hline $\begin{array}{l}\text { Seminal vesicle } \\
\text { Prostate }\end{array}$ & 0.018 & \pm 0.001 & 0.025 & \pm 0.001 & 0.028 & \pm 0.006 & $0.038 \pm$ & \pm 0.002 \\
\hline
\end{tabular}

a) Rat was injected intravenously with $100 \mu \mathrm{g}$ of ${ }^{131} \mathrm{I}$-Parotin-Subunit $\left(9.7 \times 10^{6} \mathrm{cpm}\right) / 100 \mathrm{~g}$ rat.

b) the percentage of ${ }^{131} \mathrm{I}$ which localized in each tissue to the total administrated ${ }^{131}$ I-Parotin-Subunit (mean \pm S.E.) 
れた放射活性を測定した．その結果 Table 3 亿示す如く組織湿重量（mg）当りの放射能で表わした各組 織の濃度分布では投与 5 分の群で肝臓に最も高濃度に分布し続いて腎臟, 脾臓に高濃度に分布するととを認 めた。 また時間の経過とともに甲状腺に非常に多くの放射活性が分布し, その他耳下腺, 龥下腺, 睪丸およ び副性器（性のう腺および前立腺）などでは放射活性が長時間 retentionするととを認めた。一方組織当 りの分布百分率で表わすと Table 4 亿示す如く投与 5 分では全投与量の約 $60 \%$ が肝臟に分布した. また甲 状腺，睪丸および副性器で時間の経過とともに分布の増加を認めた。

Parotin-Subunit 投与ラットにおける各䁍器および 血漿中の Cyclic AMP レベルの変動

Parotin-Subunit の生理作用機序解明の一端として多くのホルモンの second mediator と考えられてい るCyclic AMP を取り上げ, ${ }^{131} I-P a r o t i n-S u b u n i t$ の分布が多く認められた肝臟, 腎臟, 脾臟およびこれ まで知られている唾液腺ホルモン関連臟器中の Cyclic AMP レベルに及ぼす影響を in vivoにて検討した。 その結果, 臟器中の Cyclic AMP レベルは Table 5 に示す如く骨端部骨および靧下腺において投与 5 分 ないし20分後に有意な增加を示した。しかし ${ }^{131}$ I-Parotin-Subunit の分布が多く認められた肝臓，腎臟お よび脾臟においては何ら有意な変動は認められなかった。まま血獎中の Cyclic AMP レベルは Table 6 に示す如く投与 5 分および20分の群において有意な増加を示した。

Table 5. Effect of Parotin-Subunit on Cyclic AMP level of Rat Tissues

\begin{tabular}{|c|c|c|c|c|}
\hline \multirow[t]{2}{*}{ Group } & \multicolumn{4}{|c|}{$\begin{array}{l}\text { Cyclic AMP level }(\mu \mu \text { mole } / \mathrm{mg} \text { wet tissues }) \\
\text { Time after injection }{ }^{\text {a) }} \text { (min) }\end{array}$} \\
\hline & 0 & 5 & 20 & 180 \\
\hline Parotid gland & $0.44 \pm 0.09^{\mathrm{b})}$ & $0.49 \pm 0.06$ & $0.46 \pm 0.05$ & $0.57 \pm 0.10$ \\
\hline Submaxillary gland & $1.02 \pm 0.01$ & $1.34 \pm 0.12^{*}$ & $0.88 \pm 0.05$ & $0.97 \pm 0.04$ \\
\hline Liver & $0.36 \pm 0.05$ & $0.34 \pm 0.16$ & $0.20 \pm 0.06$ & $0.27 \pm 0.03$ \\
\hline Kidney & $0.72 \pm 0.03$ & $0.79 \pm 0.03$ & $0.73 \pm 0.04$ & $0.81 \pm 0.06$ \\
\hline Spleen & $0.52 \pm 0.09$ & $0.36 \pm 0.07$ & $0.29 \pm 0.04$ & $0.46 \pm 0.07$ \\
\hline Testis & $0.14 \pm 0.04$ & $0.18 \pm 0.02$ & $0.18 \pm 0.05$ & $0.31 \pm 0.06$ \\
\hline Metaphyseal bone & $0.62 \pm 0.01$ & $1.22 \pm 0.28^{*}$ & $1.02 \pm 0.10^{* *}$ & $0.77 \pm 0.02$ \\
\hline
\end{tabular}

a) Rat was injected intravenously with $100 \mu \mathrm{g}$ of Parotin-Subunit/100 g rat.

b) mean \pm S.E. $(\mathrm{n}=4)$

* $\mathrm{p}<0.05, * * \mathrm{p}<0.01$ significant difference from $0 \mathrm{~min}$ value

Table 6. Effect of Parotin-Subunit on Cyclic AMP level of Rat Plasma

\begin{tabular}{l|c|c|c|c|c}
\hline \multirow{2}{*}{ Group } & \multicolumn{5}{|c}{ Cyclic AMP level $(\mu \mu$ mole/50 $\mu 1$ plasma $)$} \\
& \multicolumn{2}{|c|}{ Time after injection ${ }^{\mathrm{a}}(\mathrm{min})$} \\
\hline Plasma & 0 & 5 & 20 & 60 & 180 \\
\hline & $0.65 \pm 0.09^{\mathrm{b})}$ & $1.50 \pm 0.22^{*}$ & $1.61 \pm 0.52^{*}$ & $0.93 \pm 0.47$ & $0.42 \pm 0.05$ \\
\hline
\end{tabular}

a) Rat was injected intravenously with $100 \mu \mathrm{g}$ of Parotin-Subunit/100 g rat.

b) mean \pm S.E. $(n=8)$

* $\mathrm{p}<0.05$ significant difference from $0 \mathrm{~min}$ value

\section{Parotin-Subunit および MP-Parotin の Adenyl cyclase 活性に及ぼす影響}

in vivoにおいて Parotin-Subunit 投与によりラットの骨端部骨で投与後 5〜20分後に Cyclic AMP レ ベルの有意な上昇が認められていることから，骨端部骨の無細胞系において Parotin-Subunit および MPParotin の Adenyl cyclase 活性に及ぼす影響を検討した. その結果 Table 7 に示すように骨端部骨にお いて NaF により賦活化される Adenyl cyclase 分画を見い出し, その活性が Parotin-Subunit の添加に 
Table 7 Effects of Parotin-Subunit and MP-Parotin on Adenyl Cyclase in Bone

\begin{tabular}{l|c|ccccc}
\hline \hline \multirow{3}{*}{ Tissue } & Addition & \multicolumn{5}{|c}{ Cyclic AMP formed } \\
& & Exp. 1 & Exp. 2 & Exp. 3 & Exp. 4 & Exp. 5 \\
\hline \multirow{2}{*}{ Bone } & None & 15.6 & 28.8 & 23.0 & 33.0 & 30.0 \\
& Parotin-Subunit & & & & & \\
& $100(\mu \mathrm{g} / \mathrm{ml})$ & 30.0 & 40.8 & 36.0 & 72.6 & 67.5 \\
& 50 & 30.0 & 36.0 & 32.0 & 75.9 & 67.5 \\
& 25 & 31.2 & 38.4 & 30.0 & 66.0 & 58.5 \\
& 12 & 25.2 & 37.2 & 26.0 & 46.2 & 52.5 \\
& 6 & 22.8 & 33.6 & 24.0 & 49.5 & 27.9 \\
& $\mathrm{MP}-\mathrm{Parotin}$ & & & & & \\
& 50 & 26.4 & - & - & 62.7 & 58.5 \\
& 12 & 16.8 & - & - & 49.5 & 42.0 \\
& $\mathrm{NaF}\left(10^{-2} \mathrm{M}\right)$ & 74.4 & 43.2 & 64.0 & 85.8 & 87.0 \\
\hline \multirow{2}{*}{ Brain } & $\mathrm{None}$ & - & - & 52.8 & 25.9 & 29.6 \\
& $\mathrm{NaF}\left(10^{-2} \mathrm{M}\right)$ & - & - & 561.0 & 814.6 & 740.6 \\
\hline
\end{tabular}

より 1.5〜2倍に上昇することを認めた. また Parotin-Subunit の原料である MP-Parotin にあ弱いが Adenyl cyclase を賦活化することを認めた.さらに同時に行なった脳から調製した Adenyl cyclase 分画 にも, Chase ら の報告通り $\mathrm{NaF}$ により賦活化される強いAdenyl cyclase 活性を認めた.

\section{Parotin-Subunitおよび MP-Parotin の Anabolic 作用}

${ }^{131}$ I-Parotin-Subunit が投与後肝臓に高濃度に分布するととおよび睪丸，副性器に長時間 retentionされ ることから Parotin-Subunit が蛋白代謝に関与しているのではないかと考え，まずマウス肚門挙筋重量増 加法により anabolic 作用の検討を行なった. その結果 Table 8 に示す如く, 去勢して Parotin-Subunit を投与した群は去勢して生理食塩水のみを投与した群に対して有意な增加を示し Parotin-Subunit が anabolic 作用を有することを認めた。また MP-Parotin も弱いながら挙筋重量を増加させた。

Table 8. Anabolic Action of MP-Parotin and Parotin-Subunit by Increase of $\mathrm{M}$. levator ani Weight

\begin{tabular}{l|c}
\hline \multicolumn{1}{c|}{ Group } & $\begin{array}{c}\text { M. levator ani weight } \\
(\mathrm{mg} / 25 \mathrm{~g} \text { mouse })\end{array}$ \\
\hline Normal & $14.72 \pm 0.76^{\mathrm{a})}$ \\
Castrated & $8.02 \pm 0.62$ \\
Castrated + MP-Parotin & $9.74 \pm 0.75$ \\
Castrated + Parotin-Subunit & $11.71 \pm 1.12^{*}$ \\
\hline
\end{tabular}

a) mean \pm S.E. $(n=7)$

* $\mathrm{p}<0.05$ significant difference from castrated group

\section{Parotin-Subunit のC末端アミノ酸配列の同定}

各種 Parotin との化学的異同を検討するため Parotin-Subunit の C 末端アミノ酸の同定を行なった. Fig. 1 に示したように Parotin-Subunit からカルボキシペプチダーゼAにより経時的に遊離してくるアミ 


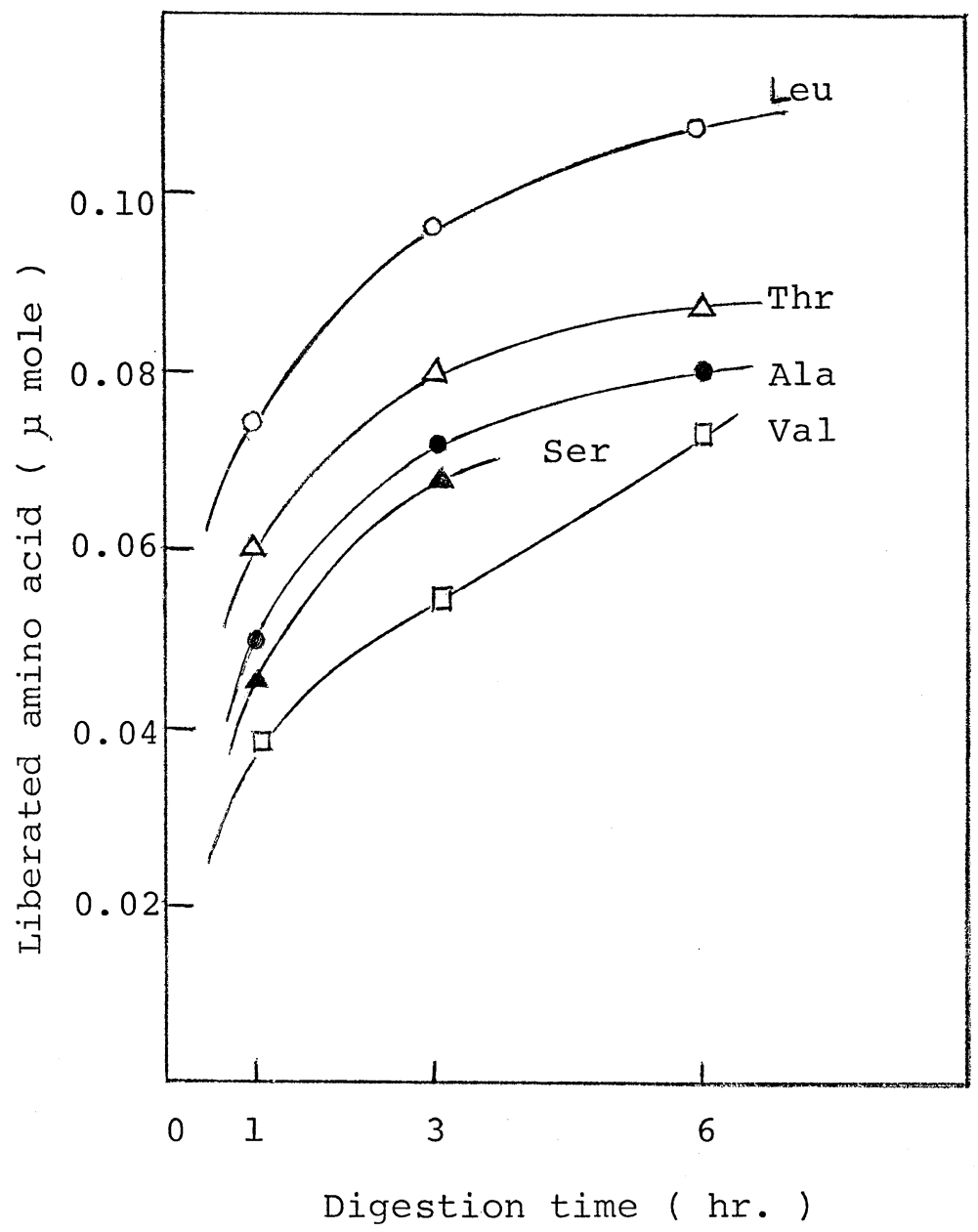

Fig. 1. Time Course of Amino Acids Liderated from Parotin-Subunit by Carboxypeptidase A

ノ酸を定量した結果, 最初に Leu が, 続いて Thr, Ala, Ser, Val が遊離してくることから ParotinSubunit のC末端アミノ酸は遊離のカルボキシル基を持つLeu であり, そのC末端側のアミノ酸配列は -Val-Ser-Ala-Thr-Leu-OH であるととを認めた.

\section{Parotin-Subunit の糖成分の同定}

Parotin-Subunit について各種糖の呈色反応を行なった結果, フェノール硫酸法, オルシン-塩化鉄-塩酸 法, オルシン一第二鉄塩-塩酸法, カルバゾール硫酸法, Blix 変法による呈色反応が陽性で, Parotin-Subunit の構成糖としてウロン酸とアミノ楉の存在を認めたが, しかしへキソースとシアル酸はまったく検出されな かった. そとでグルクロン酸を標準としてフェノール硫酸法, オルシン-第二鉄塩-塩酸法およびカルバゾー ル硫酸法によりウロン酸の定量を行なった。その結果それぞれ $1.66 \% ， 1.53 \%$ および1.73\%の值を得，い ずれの方法により定量してもほぼ一定の值となり Table 9 亿示す如く平均 $1.64 \%$ あ゙あた. またアミノ糖 はグルコサミンを標準として定量を行ない1.65\%の值を得た。 
Table 9. Sugar Component of Parotin-Subunit

\begin{tabular}{l|c|c|c}
\hline Component & Residue(\%) & $\mathrm{g} / 45,000$ & Approximate residue/45, 000 \\
\hline $\begin{array}{l}\text { Pentose } \\
\text { Hexsose }\end{array}$ & Non & & \\
$\begin{array}{l}\text { Uronic acid } \\
\text { (as glucronic acid) }\end{array}$ & 1.64 & 738.0 & $3.8(4)$ \\
$\begin{array}{l}\text { Amino sugar } \\
\text { (as glucosamine) } \\
\text { Sialic acid }\end{array}$ & 1.65 & 742.5 & $4.1(4)$ \\
\hline
\end{tabular}

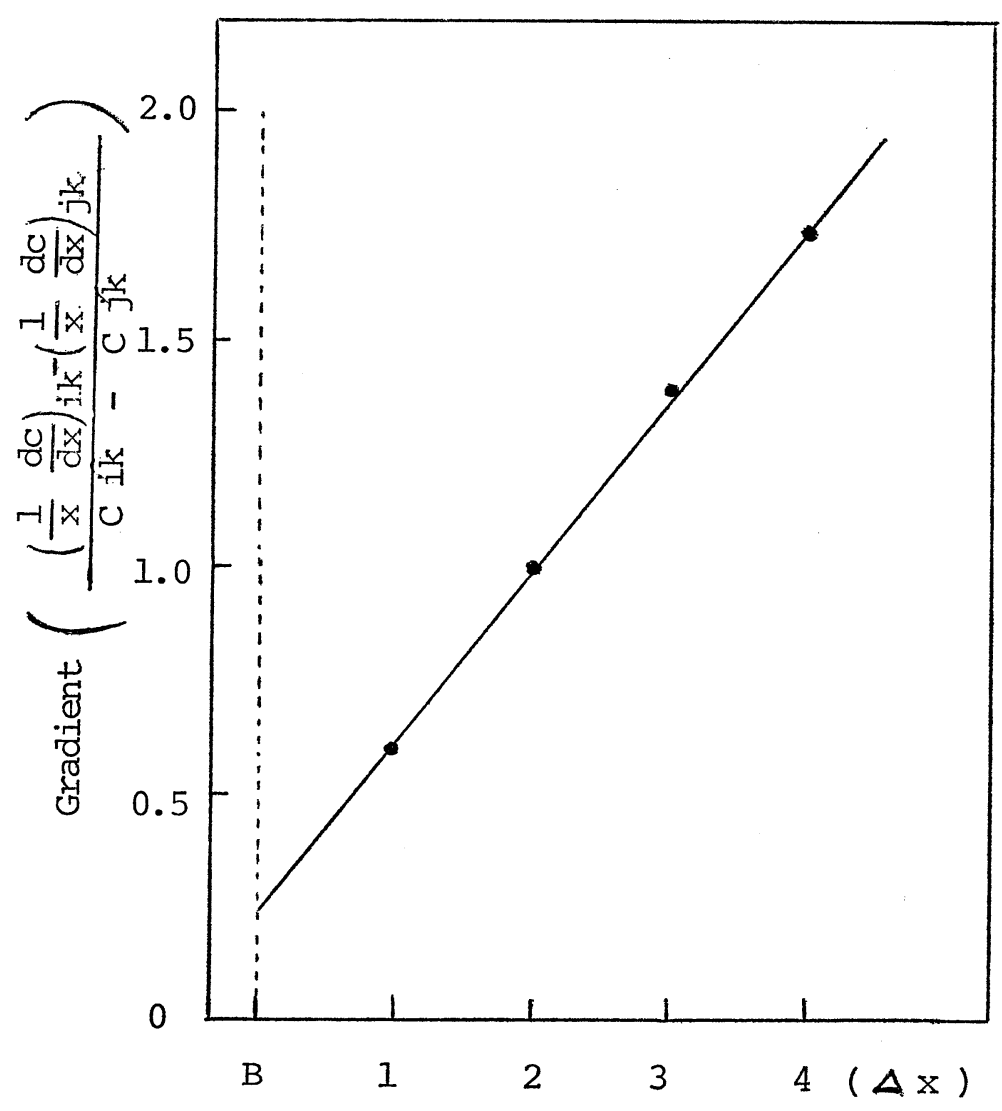

Fig. 2. Sedimentation Equilibrium Data of Parotin-Subunit $1 \%$, in $1 / 15 \mathrm{M}$ Phosphate Buffer ( $\mathrm{pH} \mathrm{8.0),}$ at $20^{\circ} \mathrm{C}$, at $6,500 \mathrm{rpm}$, Phase angle : $70^{\circ}$

\section{沈降平衡法による分子量の測定}

Archbald 法 ${ }^{11}$ に従って初濃度を 1.0 とおき $\mathrm{C}^{\prime}{ }_{\mathrm{ik}}$ と $(\mathrm{dn} / \mathrm{dx}) / \mathrm{x}$ のプロットから $\Delta \mathrm{x}$ の值の傾斜を求 
め, Fig 2 に示すようにボトムへの外插值を求めると，0.235 となり

$$
M=\frac{\left(\frac{1}{\mathrm{x}} \frac{\mathrm{dc}}{\mathrm{dx}}\right)_{\mathrm{ik}}-\left(\frac{1}{\mathrm{x}}-\frac{\mathrm{dc}}{\mathrm{dx}}\right)_{\mathrm{jk}}}{\mathrm{C}_{\mathrm{ik}}-\mathrm{C}_{\mathrm{jk}}}\left(\frac{\mathrm{RT}}{(1-\nu \rho) \omega^{2}}\right)
$$

の式から分子量を求めると 45,300 となるととを認めた。なおこの值は既に報告したディスク電気泳動法によ る分子量測定結果と一致した.

$$
\text { 考察 }
$$

Parotin-Subunit が MP-Parotin と同様家鬼において血清 Ca 低下作用を示すが, その作用機作は現在 不明である. Calcitonin の Ca 低下作用について Johnston ら ${ }^{15)}$ は Calcitonin が骨安定分画に対して骨 吸収を抑制するととにより血清 $\mathrm{Ca}$ 低下作用を引き起とすととを報告しているが，著者らす今回家鬼を用い Parotin-Subunit および MP-Parotin が骨安定分画の Ca を上昇させるととを見い出し，Calcitonin 之は 異なり骨吸収抑制には何ら関与していないととを諗めた。また Calcitonln とはCa 変動の time course が

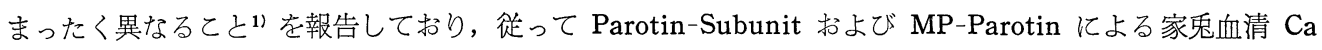
低下作用は骨安定分画の Ca の移動に直接関与していることを認めた。

Parotin-Subunit の体内分布をParotin 関連物質と比較検討する目的でラットにおいて ${ }^{131}$ I-ParotinSubunitを用い所定時間後の各臟器中の放射能分布を調べた。 その結果 Parotin $^{122,200,21)}$, S-Parotin, 血清 Parotinについては著者ら ${ }^{31}$ にりその ${ }^{131}$ I-標識物のラットにお抢る分布が報告されているが, ${ }^{1311}$ I-ParotinSubunit の場合, 肝臟, 腎臓, 脾臟に比較的多量に分布し, Parotin-Subunit, 血清 Parotin とも類似した 分布を認めた。また甲状腺では時間の経過とともに急速に分布を増し，他の唾液腺ホルモン関連物質の挙動 と一致した. また ${ }^{131} \mathrm{I}$-Parotin-Subunit が肝臟において短時間に多くの分布を示すとと, 性殖器への retention がみられることおよび肛門挙筋法による anabolic 作用がみられるととより， S-Parotin および

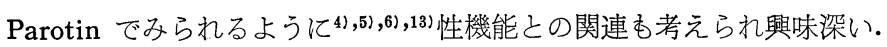

Sutherland ${ }^{181}$ とより発見された Cyclic AMP がある種のホルモンの second mediator として働いている ことが知られ，ての Cyclic AMP はホルモンによって細胞膜に結合した酵素である Adenyl cyclase の賦 活化によって細胞内濃度を増し，それに引き続き Cyclic AMP dependent protein kinase を活性化する22 というホルモン細胞内作用機作が明らかになってきた。そこで Parotin-Subunit が Adenyl cyclase-Cyclic AMP 系に対してどのような影響を与えるか検討を加えた結果, ラットにおいて in vivo で Parotin-Subunit 投与後の各臟器中の Cyclic AMPレベルは骨端部骨之顎下腺において投与 5 20分後に有意な増加を示し, また血獎中の Cyclic AMP レベルも有意な増加を示した。 そこで唾液腺内分泌が硬組織に関係あること ${ }^{14)}$ から骨端部骨を取り上げ無細胞系において Parotin-Subunit および MP-Parotin による Adenyl cyclase

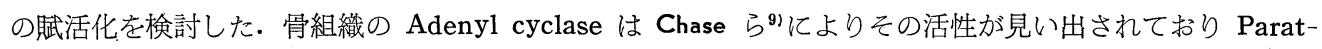
hyroid hormone により賦活化されるととが報告されているが, 著者らも骨端部骨のホモジネートの 2,200 × $\mathrm{g}$ フラクションに NaF により賦活化される Adenyl cyclase 分画を得, その活性が Parotin-Subunit および MP-Parotin により直接賦活化されるととを認めた。従って骨端部骨の Adenyl cyclase の賦活化 により濃度を増した Cyclic AMP がなんらかのホルモン作用を発現している可能性が認められた。一般に 骨を形成する細胞は 3 種あり, 骨の基質形成および石灰化沈着に関与する造骨細胞 (osteoblast), 骨中に多 量に分布し時には骨吸収に関与する骨細胞 (osteocyte) および主として骨基質および無機質の吸収および破 壊に関与する破骨細胞 (osteoclast) があげられるが，家鬼およびラットにおいて Parotin の石灰化促進作 用か諗められているとと ${ }^{14)}$ ，および今回得られた家鬼において血清 $\mathrm{Ca}$ 低下作用が骨吸収には関与していな いととから，Parotin-Subunit および MP-Parotin は主に造骨細胞の Adenyl Cyclase を賦活している可 能性が示唆された。

Parotn-Subunit および Parotin 関連物質の化学的異同については Parotin-Subunit のC末端アミノ酸 
はParotin および S-Parotin のC末端アミノ酸 Ala, Gly, Leu ${ }^{8)}$ のうち Leu であり，カルボキシペプ チダーゼにより遊離してくるととから Leu は遊離のカルボキシル基を持つととが判明した.

結 論

1）唾液腺ホルモン Subunit の有する血清 $\mathrm{Ca}$ 低下作用は骨安定分画の $\mathrm{Ca}$ の移動に関与しているとと を認め, その生体内分布は ${ }^{131}$ I-Parotin-Subunit を用いて, 肝臟, 粲臟, 脾臟に多く, 耳下腺, 頢下腺, 睪丸，副性器等で長時間 retention するととを認めた。

2）本物質はラットに扔いて in vivo で骨端部骨，頢下腺および血奬中の Cyclic AMP レベルを 5〜20 分後に有意に増加させた.

3）本物質はラット骨端部骨の Adenyl cyclase 活性を増加させた.

4）本物質は肚門挙筋重量増加法により anabolic 作用の有するととを認めた.

5）本物質のC末端アミノ酸配列は-Val-Ser-Ala-Thr-Leu-OH である.

6）本物質は $3.3 \%$ の糖を含み，その構成糖はアミノ糖とウロン酸から成る.

謝辞＼cjkstart最後に実験試料の一部を提供された帝国藏器製薬株式会社に心から感謝する。

文献

1）青沼繁, 小浜靖弘, 中陳静男, 屋敷伸治, 江川宏: 目液腺ホルモンの Subunit に関する生理化学的研究, 日内分泌会誌, $50: 1468-1476,1974$.

2）青沼繁, 三村務, 金在萬, 乾容子 : Bacillus 属細菌の 産生する生理活性物質の研究（第 3 報） B. subtilis K により産生され家鬼血清カルシウム低下性物質の単 離之その性質, 薬学雑誌, $92: 539-545,1972 . \quad 3$ ) 青沼繁, 三村務 : ${ }^{131} \mathrm{I}$ 標識血清パロチンの研究, 生化学, 32:528-530, 1960 . 4 4) Aonuma, S., Hama, T. and Mayumi, T. : The distribution of ${ }^{131}$ I-labelled parotin into the muscle tissue of normal and ovariectomaized guinea pig sensitised

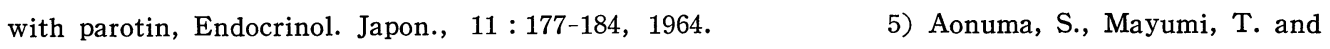
Tanaka, T. : Relationship between salivary gland hormone and sexual function(3) The effect of parotin, S-parotin and serum-parotin on progesterone metabolism, Yakugaku Kenkyu, 38:3-12, 1967. 6) 青沼繁, 真弓忠範, 中島敏彦, 鈴木宏治 : 唾液腺ホルモンと性機能（第 4 報）モルモッ 卜精液汇対するパロチンの作用, 日内分泌会誌, $46: 127-138,1970 . \quad 7$ ) 青沼繁, 真弓忠範, 中島 敏彦, 鈴木宏治 : 唾液ホルモンの下垂体前葉 FSH， LH 活性に対する作用および下垂体剔出，去勢などに よる唾液腺ホルモンの変動, 日内分泌会誌, $46: 139-147,1970 . \quad 8$ 8) 青沼繁, 浜堯夫, 真弓忠範 : 蕷下腺の研究 (第13報) S-parotin の分子量とその構成アミノ酸, 唾液腺シンポジウム, $9: 57-60,1967$. 9) Chase, L.R., Fedak, S.A. and Aurbach, G.D. : Activation of skeletal adenyl cyclase by parathyroid hormone in vitro, Endocrinology, $84: 761-68,1969 . \quad 10)$ Greenwood, F.C., Hunter, W. M. and Glover, J.S. : The preparation of ${ }^{131}$ I-labeled human growth hormone of high specific radioactivity, Biochem. J., $89: 114-123,1963 . \quad 11 ）$ 林勝哉 : 蛋白質の分子量・分子形, 東京大 学出版会, 東京, 1971, p.31 47. 12) Ito, Y., Kim, Y.E. and Tanaka, S. : Study on the salivary gland hormones labeled with ${ }^{131}$ I, 3 : Effect of ligation of several blood vessels on the degradation and distribution of ${ }^{131} \mathrm{I}$-labeled parotin in vitro, Endocrinl. Japon., $5: 201-207,1958$. 13）伊藤四十二, 青沼繁, 篠田雅人: 㖽下腺の研究, 顎下腺之睪丸の関係に就いて, 内分泌, $1: 79-88$, 1954. 14) Ito, Y. : Parotin : A salivary gland hormone, Ann. N.Y. Acad. Sci, $85: 228-310$, 1960. 15) Johnston, C.C.Jr. and Davis, W.P.Jr., An inhibitory effect of thyrocalcitonin on calcium release in vivo and on bone metabolism in vitro, Endocrinogy, $78: 1139-1143,1966$.

16) Lowry, O.H., Rosebrough, N.J., Farr, A.L. and Randal, R.J. : Protein measurement with the folin phenol reagent, J.Biol. Chem., 193 :265-275, 1951.

17) Sutherland, E.W., Rall, T.W. 
and Menon, T. : Adenyl cyclase I. Distribution, preparation, and properties, J.Biol. Chem., 237 : 1220-1227, 1962. 18) Sutherland, E.W. and Rall, T.W. : Fractionation and characterization of a cyclic adenine ribonucleotide formed by tissue particles J. Biol. Chem., $232: 1077-1091,1958$. 19）高木敬次郎, 小澤光 : 薬物学実験, 南山堂, 東京, 1973, p.168〜 170.

20) Tanaka, S. and Ito, Y. : Studies on the salivary gland hormones labeled with ${ }^{131}$ I, 1 : Localization of radioactivity after administration of ${ }^{131}$ I-labeled parotin to rats, Endocrinol. Japon., $5: 55-64,1958$.

21) Tanaka, S., Kim, Y.E. and Ito, Y. : Studies on the salivary gland hormons labeled with ${ }^{181}$, $2:$ Studies on the localization and degradation of parotin in vivo with ${ }^{131} \mathrm{I}$-labeled parotin, Endocrinol. Japon., $5: 65-69,1958 . \quad 22)$ Walsh, D.A., Perkins, J.P. and Krebs, E.G. : An adenosine 3', 5'-monophosphate-dependant protein kinase from rabbit skeletal muscle, J.Biol. Chem., 243 : 3763-3765, 1968 2 23) 山川民夫 : 生体構成成分 2 , 中山書店, 東京, 1972, p.102 110. 